\title{
Translingual Dispositions, Multilingual P-Pop and the Fight for Philippine Languages Online
}

\author{
Ruanni Tupas \\ Institute of Education \\ University College London \\ London, United Kingdom \\ ORCID: 0000-0003-2569-702X
}

\begin{abstract}
This paper discusses and maps out an instantiation of everyday multilingualism online. It argues that translingual dispositions - ways of speaking, thinking and doing which embrace, rather than reject, all forms of linguistic difference - are an important component in the struggle for the survival and maintenance of languages in the Philippines. Such dispositions, for example, are harnessed online through the promotion of 'multilingual P-Pop' (Pilipino Pop). The pandemic has made it doubly difficult to engage with issues of multilingualism, especially because one battleground for such issues are now online. However, it is not (yet) a lost battle. Willingness to communicate with the intention to understand and listen to others allows one to negotiate meaning through various strategies of online intercultural communication.
\end{abstract}

Keywords-multilingualism, translingual dispositions, language maintenance

\section{INTRODUCTION}

As much of the world has moved towards online work and communication - generating and amplifying unequal access to digital platforms - relevant inquiry questions have likewise moved to account for the dynamics of power, ideology and practice when people interact online. For sociolinguistics broadly the study of language in society - the role of language and discourse in facilitating and structuring communication online (including how online language use includes and excludes groups of people), as well as the presence and future of multilingualism, are some of the key issues that have been amplified because of the greater need for people to communicate/interact/transact/negotiate online [1].

In this paper, I will discuss in some detail how 'multilingualism' is operationalized and contested online, and how such operationalization and contestation result in particular intercultural communication dynamics through negotiation of meaning despite the use of different languages. The context of my discussion is the mobilization of the notion of 'multilingual P-Pop' (Pilipino Pop) which draws broadly on the pop music genre but with shades or influences of Filipino music and culture [2]. The paper argues specifically that there are spaces for multilingualism online which give hope for the support for or promotion of Philippine languages which are increasingly being displaced by Filipino, the national language, and also marginalized discursively and politically by the symbolic and material dominance of the English language. Such spaces are made possible by what is referred to as translingual dispositions [3] or ways of thinking and doing which embrace linguistic differences rather then treat them as problems in education and society.

\section{Contextualizing Multilingual P-PoP}

The template is used to format your paper and style the text. All margins, column widths, line spaces, and text fonts are prescribed; please do not alter them. You may note peculiarities. For example, the head margin in this template measures proportionately more than is customary. This measurement and others are deliberate, using specifications that anticipate your paper as one part of the entire proceedings, and not as an independent document. Please do not revise any of the current designations.

I will situate my discussion within the dynamics of communication among the fans of SB19, a phenomenal boy group from the Philippines. The group is a five-member group which currently appears on Billboard charts as among the most social media-engaged artists in the world, has been for at least eight weeks the most requested artists on MTV and, in the Philippines, is a multi-awarded group with a huge fanbase. Because of the pandemic, and just like all other artists, SB19 has been pushed to deliver content online, thus the need to engage with fans and other online users has never been more pressing for this group. It has developed ways of engagement with fans, thus generating specific arrangements of online communication which involve use of different languages, ideologies of language, and intercultural encounters. The question of language - or multilingualism for that matter - has come up from time to time because of the group's evolving identity as a Filipino boy group. Being the first Filipino group to have trained under a Korean training system, the group has had to deal with criticism of its over-all identity as Filipino artists. From evidently K-Pop styling, it has gradually distanced itself from it, still with K-Pop influences in terms of music but now with visual styling associated more with being Filipino, on top of using the Filipino language and incorporating the cultural nuances of hugot [4] or affective propensity towards overly sad ballad songs.

Thus, among the group, and with the strong push of the fanbase, there has been an undeniably conscious effort to transform the group's identity towards what may be defined as P-Pop, rather than K-Pop. P-Pop is an evasive concept, but it is precisely because of its unclear meaning that its transforming potential has become a central talking point in the Philippines. Consequently, and understandably, the use of language in the contested nature of P-Pop has been recognized 
as one of the key features of the emerging local genre [5], but because the Philippines is a multilingual country, with more than 100 languages spoken across the archipelago, there are emerging voices which push P-Pop beyond the use of the national language, Filipino, and to incorporate regional languages (and cultures) as well. This continuing engagement with the identity of SB19 has shaped how the artists and their fans relate to each other online, and this then has implications for how multilingualism (both as practice and ideology) operates in the fandom.

This paper describes one instance of everyday multilingualism within the fandom which will hopefully illustrate how translingual dispositions can help promote the use of Philippine languages which, as mentioned earlier, is slowly being eroded by the dominance of the national language as well as the enduring colonially-induced influence of the English language [6]. This concerns the use of Bisaya, one of the major regional languages in the Philippines, by one of the group's members, Ken Suson. One particular use of the language has surfaced translingual dispositions which allowed for the negotiation of meaning among fans despite the socalled 'language barrier'. What such an instance of language use, in fact, has shown is that communication is possible even if interlocutors do not use the same language. What is needed in communication is not necessarily the use of only one common language but, more importantly, the willingness to communicate and to understand each other despite the superficial limits of language.

\section{TRANSLINGUAL DisPositions ONLINE}

Recently, Ken Suson screencapped a short conversation he had with his dad and shared it on Twitter. Ken introduced it in English -- "This kind of conversation with your father" - but the conversation was in Bisaya, with very minimal use of English.

\section{Ken : Bitaw pa no \\ Taga bukid ra biya}

Dad : Unsa man diay?..huna hunaa gani kon unsa ta ka pobre atong gamay paka nagsakay tag habal habal nga napaso ko...lisod tag palit ug ginanggang.

Ken : Kahinumdum jud ko atong natumba ka HAHAHAH na shoot ta sa kanal hahaha Gamaya pa nako ato oy HAHAHA

Dad : Na kon imong imaginon daw gahapon lang pero wala nato damha nga naabot naka sa top of the world...hahaha..

Ken : Di pa na top of the world pa uyyy HАНАНА sa future papa i top of the world tana

This paper analyses the dynamics of communication that ensued after Ken shared it online, thus the meaning of the conversation is not relevant to the discussion. Detailed translation is not needed, but in general the exchange between Ken and his dad essentially revolved around their life then in the 'bukid' - literally, mountain - which was difficult, but much has changed since Ken joined SB19 and has, by implication, become successful.
What Ken did is what is referred to in linguistics as a marked form or use of language [7]. In any communication context, interlocutors or speakers usually have expectations of how communication will proceed, and one of such expectations is which language or languages is/are going to be used. If the expected language or languages (or, for that matter, dialects or accents) are used, then the manner by which they are used is described as unmarked. In such cases, the communication runs smoothly. However, it is different if the use of language(s), dialect(s) or accent(s) is marked - that is, they are unexpected. It generates surprise, frustration, silence, or even anger. In such cases, speakers need time to process what is going on and adjust their expectations in order to respond appropriately. Unfortunately, not all speakers are able to process what is going on resulting in all kinds of communication breakdown.

In the case of Ken's Twitter drop of his conversation with his father, the unmarked language would have been Filipino, or translingual use of Filipino and English, because the huge majority of fans do not speak Bisaya. What is even more interesting is the fact that Ken did not provide any translation of the conversation. In this case, there is a disconnect between the language of the conversation and the unmarked language on Twitter, potentially resulting in confusion, miscommunication and feelings of exclusion. What has happened, however, betrays a specific dynamics of multilingualism where participants negotiate the meaning of a conversation by deploying strategies of meaning-making.

First of all, instead of treating the conversation in Bisaya as a 'language barrier', the fans called on Bisaya speakers to translate the meaning of the conversation, and on the part of the Bisaya speakers, they did indeed provide their respective translations in order for non-Bisaya-speaking fans to understand what the conversation was about. Second, fans who knew family members or friends who speak Bisaya counted on the latter to provide them with the translation. Third, some fans attempted to get to the meaning of the conversation through their knowledge of other Philippine languages. Although Philippine languages are not easily mutually comprehensible, they belong to the same family of languages [8], thus specific words may share similar meanings across some Philippine languages.

Consequently, more negotiation of meaning emerged out of the online threads. Apparently, certain Bisaya words used - specifically "habal-habal" and "ginanggang" -- meant differently depending on which Bisaya-speaking province or region is using it. Therefore, the translations provided generated spaces for intercultural negotiation as well in the sense that those involved in the exchanges needed to nuance their understanding of the translations. The exchanges also became spaces for intercultural understanding even among the Bisaya speakers themselves. In other words, the response to the marked use of language has been addressed through the deployment of various strategies of meaning-making, revealing a more profound nature of successful communication. Some would think of languages as potential barriers to communication, especially if they are used in contexts where not everyone is able to speak or understand it. But in this specific case of a marked form of communication, interlocutors or participants showed how communication could proceed successfully despite the use of language(s) they did not understand. 
This phenomenon is referred to as willingness to communicate [9]. Much of communication breakdown is not simply a result of people using different languages, dialects or accents, but also of people who do not trust each other or those who are not willing to understand others due to a variety of reasons, for example the former's low social regard of others, their stereotype of others as backward or uneducated, and so on. In other words, we do not understand each other not only because of the so-called 'language barrier', but because we refuse to do so, and there are all sorts of cultural, political and ideological reasons for this.

Therefore, what we have seen are translingual dispositions in action online. Such dispositions are the totality of people's embracive and positive attitudes and practices which acknowledge multilingualism as resource for meaningmaking, rather than as barriers to communication [10]. Ideologically speaking, there are people and institutions that treat the presence of different languages, dialects and accents as social problems which need to be eliminated [11]. Many language policies, in fact, are ideologically aligned with this position, thus only one or two languages are typically recognized as legitimate languages while all other languages in society are considered irrelevant or useless, thus must be eliminated [12]. In language teaching and learning, translingual dispositions are ways of speaking, thinking and doing which do not only accommodate the use of students' languages, dialects and accents, but in fact also make use of them as resource of teaching. Similarly in this case, multilingualism in the classroom, for example in the English language classroom, is considered a pedagogical resource, not a pedagogical problem [13].

\section{PhilipPINE LANGUAGES ONLINE}

Philippine languages have historically been marginalized due to colonialism and the dominance of English [14]. This has been exacerbated in recent decades because of the institutionalization of bilingual education in English and Filipino (the national language) [15]. Despite mother tonguebased multilingual education in the early years of formal education, most Philippine languages remain neglected or devalued precisely because of systemic structures and ideologies which continue to privilege English and Filipino. Because of the pandemic, the future of Philippine languages has become even more unsure or perilous. How does one promote the use of these languages online?

First of all, structures of communication online are skewed towards dominant languages such as English and Filipino. And while several other regional languages do appear online and are used by a good number of people, the Philippine languages in general are positioned ideologically as the marked languages of online communication [16], thus making it difficult for their speakers to assert themselves in intercultural conversations or interactions online. A case in point is the fact that the Philippine languages continue to suffer from speakers' internal colonization. This means that Filipinos themselves in general refer to their languages as 'dialects', not languages, and this can be traced back to centuries of colonizations, first with the Spanish, and second with the Americans [17]. Calling Philippine languages 'dialects' downgrades these languages but this is not an isolated politics of language; in fact, the naming of Philippine languages as 'dialects' does implicate broader social inequalities which concern how speakers of these languages are treated by society.

Thus, the case of the conversation between Ken and his father is a rich sociolinguistic and cultural resource for mapping how the fight for Philippine languages online might look like. As mentioned in the preceding section, the inculcation of translingual dispositions is paramount in the promotion of languages. There are strategies of constructive and positive meaning-making which can be harnessed online, for example through partnership with artists such as SB19 who on their own also engage in identity-making via multilingual P-Pop. Language maintenance strategies have always included the promotion of languages through song and art [18]. It is an uphill battle, of course, especially because online structures make it more challenging to get people to use their own local languages, but it is not (yet) a lost battle. Willingness to communicate with the intention to understand and listen to others allows one to negotiate meaning through various strategies of online intercultural communication. Multilingualism online should not be treated as a nuisance or a problem that must be eliminated. Just like 'multilingual PPop', the presence of many languages online is a source of meaning and identity.

\section{CONCLUSION}

Of course, it must be emphasized that the presence of many languages online is ultimately a systemic problem. Beyond meaning and identity, the central question revolves around social inequalities or 'inequalities of multilingualism' [19] which cannot be solved simply by more use of Philippine languages. Language issues are political, cultural and socioeconomic issues as well since those who typically speak the minoritized languages are likewise the most marginalized people in society. If they are silenced due to their languages, it is because they are also silenced for being who they are [20].

Nevertheless, if we view the promotion of languages online as intricately linked with other forms of advocacy and social agenda, then translingual dispositions are not mere ideologies or practices per se but are structurally formed ways of talking, thinking and doing things. Such dispositions are reflective and indicative of social spaces which allow for dialogues to occur between speakers of different languages: they point to all sorts of social differences (including linguistic differences) as resource for and means of addressing social inequalities.

\section{REFERENCES}

[1] J. Blommaert, J., "From groups to actions and back in online-offline sociolinguistics," Multilingua, 38(4), pp. 485-493, 2019.

[2] R. Tupas, "Filipino scholar analyzes SB19 Ken Suson, P-Pop as multilingual genre," https://www.philstar.com/entertainment/koreanwave/2020/08/28/2038458/buwan-ng-wika-filipino-scholar-analyzessb19-ken-suson-p-pop-multilingual-genre, Aug 28, 2020

[3] J. W. Lee and C. Jenks, "Doing translingual dispositions," College Composition and Communication, pp. 317-344, 2016.

[4] L. H. Arias, Reflecting Filipino identities through hugot in three Philippine films: A contextual and prosodic analysis, Doctoral dissertation, Iligan Institute of Technology, 2017

[5] R. Tupas, "Filipino scholar analyzes SB19 Ken Suson, P-Pop as multilingual genre," https://www.philstar.com/entertainment/koreanwave/2020/08/28/2038458/buwan-ng-wika-filipino-scholar-analyzessb19-ken-suson-p-pop-multilingual-genre, Aug 28, 2020. 
[6] R. Tupas, "The politics of 'p' and 'f': A linguistic history of nationbuilding in the Philippines," Journal of Multilingual and Multicultural Development, 36(6), pp. 587-597, 2015.

[7] I. R. Beiler, "Marked and unmarked translanguaging in accelerated, mainstream, and sheltered English classrooms," Multilingua, ahead-ofprint, 2020..

[8] A. Gonzalez, 1998, "The language planning situation in the Philippines,"Journal of Multilingual and Multicultural Development, 19(5), pp. 487-525, 1998.

[9] J. C. and V. P. Richmond, 1990, "Willingness to communicate: Differing cultural perspectives," Southern Journal of Communication, 56(1), pp. 72-77.

[10] J. W. Lee and C. Jenks, "Doing translingual dispositions," College Composition and Communication, pp. 317-344, 2016.

[11] [M. Källkvist and F. M. Hult, "Multilingualism as Problem or Resource? Negotiating Space for Languages Other Than Swedish and English in University Language Planning," in M. Kuteeva, K. Kaufhold, and N. Hynninen (eds), Language Perceptions and Practices in Multilingual Universities, Palgrave Macmillan, Cham, pp. 57-84, 2020

[12] E. Annamalai, E., "Reflections on a language policy for multilingualism," Language policy, 2(2), 113-132, 2003
[13] R. Rubdy, "Singlish in the school: An impediment or a resource?," Journal of Multilingual and Multicultural Development, 28(4), pp. 308-324, 2007.

[14] R. Constantino, "The mis-education of the Filipino," Journal of Contemporary Asia, 1(1), pp. 20-36, 1970

[15] R. Tupas, "Inequalities of multilingualism: Challenges to mother tongue-based multilingual education," Language and Education, 29(2), pp. 112-124, 2015.

[16] S. Dita and R. E. Roxas, "Philippine Languages Online Corpora: Status, issues, and prospects," in Proceedings of the 9th Workshop on Asian Language Resources, pp. 59-62, 2011, November.

[17] R. Tupas, "Inequalities of multilingualism: Challenges to mother tongue-based multilingual education," Language and Education, 29(2), pp. 112-124, 2015.

[18] C. Grant, Music endangerment: How language maintenance can help, Oxford, Oxford University Press, 2014.

[19] R. Tupas, "Inequalities of multilingualism: Challenges to mother tongue-based multilingual education," Language and Education, 29(2), pp. 112-124, 2015.

[20] C. Groff, "Language and language-in-education planning in multilingual India: a minoritized language perspective," Language Policy, 16(2), pp. 135-164, 2017. 